[Agr. Biol Chem., Vol. 32, No. 3, p. 284 286, 1968]

\title{
Physiological Studies on Thiobacilli
}

\section{Part V. Extraction of NADPH-Cytochrome c Oxidoreductase from Thiobacillus thiooxidans}

\author{
By Tatsuo Tano and Kazutami ImaI \\ Department of Agricultural Chemistry, Okayama University \\ Received July 20, 1967
}

\begin{abstract}
Electrophoretically homogenous preparation of NADPH-cytochrome $c$ oxidoreductase was isolated from the soluble fraction of Thiobacillus thiooxidans. The purification of the enzyme was carried out using the fractionation with ammonium sulfate, the treatment with Amberlite IRC-50 and the disk electrophoresis.
\end{abstract}

Numerous works on the cytochrome $\mathrm{c}$ reductase have dealt with those of animals, ${ }^{\text {" }}$ yeasts $^{21,31}$ and heterotrophic bacteria. ${ }^{4 /}$ Recently, Yates and Nason $^{51}$ demonstrated that a heat-labile iron-cytochrome $c$ reductase was isolated from chemoautotroph Ferrobacillus ferrooxidans by sonic oscillation of the cell at $\mathrm{pH} 5.5$ in the presence of protamine sulfate and purified 20 -fold by successive fractionation of the supernatant solution (centrifugation at $144,000 \times \mathrm{g}$ for $30 \mathrm{~min}$ ) with ammonium sulfate and Sephadex G-200.

In the preceding paper, ${ }^{6}$ it was reported that cytochrome $\mathrm{c}$ was found in the soluble fraction (sonic disruption under $20 \mathrm{kc} / \mathrm{s}$ for $40 \mathrm{~min}$, centrifugation at $90,000 \times \mathrm{g}$ for $60 \mathrm{~min}$ ) of $T$ thiooxidans and it was reduced by the partially purified NADPH-cytochrome c oxido-

1) H. R. Mahler, N. K. Sarkar, L. P. Vernon and R. A. Alberty, J. Biol. Chem, 199, 585 (1952).

2) E. Haas, B. L. Horecker and T. R. Hogness, J. Biol. Chem., 136, 747 (1940).

3) E. Haas, C.J. Harrer and T. R. Hogness, ibid., 143, 341 (1942).

4) A.F. Brodie, "Methods in enzymology", Vol. II, ed. by S. P. Colowick and N. O. Kaplan, Academic Press Inc., New York, 1957, p. 693

5) M. G. Yates and A. Nason, J. Biol. Chem., 241, 4872 (1966).

6) T. Tano, H. Kagawa and K. Imai, Agr. Biol. Chem., 32, 274 (1968). reductase. The present paper describes the isolation of the enzyme from $T$. thiooxidans which catalyzes the transfer of electron from NADPH to cytochrome c.

\section{MATERIALS AND METHODS}

Materials. Crystalline cytochrome $c$ of horse heart and NADPH were purchased from Sigma Chemical Co. Acrylamide monomer and N, N'-methylene bisacrylamide were obtained from Seikagaku Kogyo Co.

Spectrophotometric determination. The spectrophotometric determination was carried out using the Shimazu model MPS-50 recording spectrophotometer.

Acrylamide gel electrophoresis. Acrylamide monomer and $\mathrm{N}, \mathrm{N}^{\prime}$-methylene bisacrylamide were mixed in the ratio of $19: 1$ and $10 \mathrm{~g}$ of the mixture was dissolved in a $200 \mathrm{ml}$ of $0.1 \mathrm{M}$ Tris-borate buffer (pH 8.9) containing EDTA and gelatinized by the catalysis. Electrophoresis was carried out at a current of $8 \mathrm{~mA} / \mathrm{cm}$ width of gel for approximately $8 \mathrm{hr}$.

Immediately after electrophoresis, the gel was stained for about $3 \mathrm{~min}$ with $1 \%$ amidoschwarz dissolved in the solvent (methanol: water : acetic acid = $4: 5: 1$ ) and then destained in the solution (methanol : water : acetic acid $=8: 12: 1$ ) for $48 \mathrm{hr}$ with stirring and renewing the solution.

Disk electrophoresis. The apparatus devised for the purification of the enzyme by large scale disk electrophoresis is indicated in Fig. 1. Anionic system 


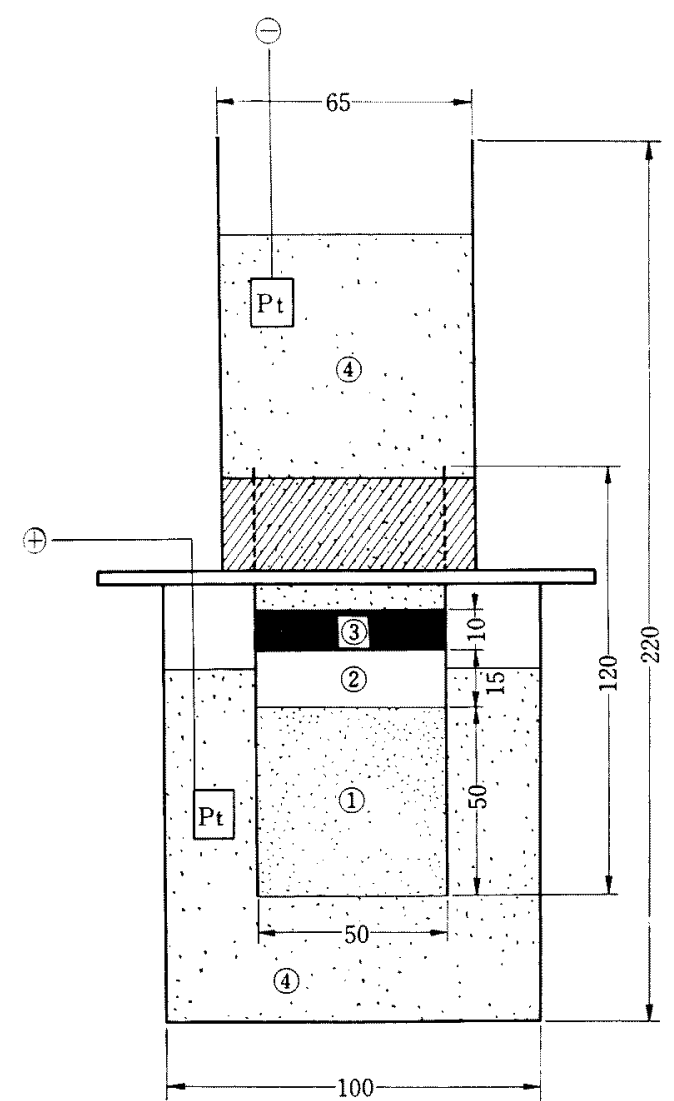

FIG. 1. Apparatus for Purification of the Enzyme by Large Scale Disk Electrophoresis.
(1) Running gel
(2) Spacer gel
(3) Sample $\mathrm{Pt}$; Platinum electrode
(4) Trismglycine buffer

was prepared according to Ornstein and Davis." The gel column $(5 \times 10 \mathrm{~cm})$ was composed of a smallpore gel, $5 \mathrm{~cm}$ high, and a large-pore gel, $1.5 \sim 2.0$ $\mathrm{cm}$ high. After cooling the apparatus, Tris-glycine buffer ( $\mathrm{pH}$ 8.6) was poured into both vessels and the sample mixed with $60 \%$ sucrose solution was piled upon the large-pore gel. Electrophoresis was carried out at a current of $35 \mathrm{~mA}$ for approximately $9 \mathrm{hr}$ keeping temperature below $5^{\circ} \mathrm{C}$.

7) L. Ornstein and B. J. Davis, Disk electrophoresis. Unpublished work. Printed by Distillation Products Industries, Div. Eastman Kodak Co. Rochester N.Y.
Assay method. The activity of NADPH-cytochrome $c$ oxidoreductase was measured spectrophotometrically by the rate of decrease in optical density due to the oxidation of NADPH in a system containing $200 \mu$ moles of Tris- $\mathrm{HCl}$ buffer $(\mathrm{pH} 8.7), 0.6$ $\mu$ moles of cytochrome c (mammalian) or $0.3 \mu$ moles of methylene blue as electron acceptor, $0.3 \mu$ moles of NADPH and the enzyme in a total volume of $3.3 \mathrm{ml}$. One unit of the enzyme activity is the amount of enzyme which causes the decrease in optical density at $340 \mathrm{~m} \mu$ of 0.1 per min at lightpath of $1 \mathrm{~cm}$.

\section{RESULTS AND DISCUSSION}

\section{Preparation of the enzyme}

The procedures employed for preparation of Fraction III (40 70\% $\mathrm{AmSO}_{4}$ saturation) was the same as those described in the preceding paper. ${ }^{8,9}$ Fraction III was subjected to chromatography of Amberlite IRC-50 column $(2 \times 5 \mathrm{~cm})$ preequilibrated with ammonium phosphate (pH 7.0). The effluent was concentrated with ammonium sulfate and the precipitate was dissolved in a small amount of $0.1 \mathrm{M}$ phosphate buffer $(\mathrm{pH} 7.0)$ and the solution dialyzed overnight at $4^{\circ} \mathrm{C}$ against the same buffer. The dialyzed solution was mixed with $600^{\circ}$ sucrose solution and applied to the above mentioned gel for disk electrophoresis. Since the Sephadex-gel filtration and DEAEcellulose or DEAE-Sephadex column chromatography proved consistently unsuccessful, it was thought effective to apply a disk electrophoresis in a larger scale than usual for the purification of the enzyme. As shown in Fig. 2 , protein components migrated separately as the thin layers, immediately after the end of electrophoresis, the gel was cut horizontally at the position indicated by arrows. The each protein was eluted from separated gel block with $0.1 \mathrm{~m}$ phosphate buffer ( $\mathrm{pH} 7.0$ ) and concentrated with ammonium sulfate and assayed respectively. The majority of cytochrome $c$

8) T. Tano and K. Imai, Agr. Biol. Chem,, 32, 51 (1968).

9) T. Tano, H. Kagawa and K. Imai, ibid., $\mathbf{3 2}$, 274 (1968). 
reported up to the present is flavoprotein, and the fraction A-III and A-IV were the yellow layers and A-I was brown, however, the

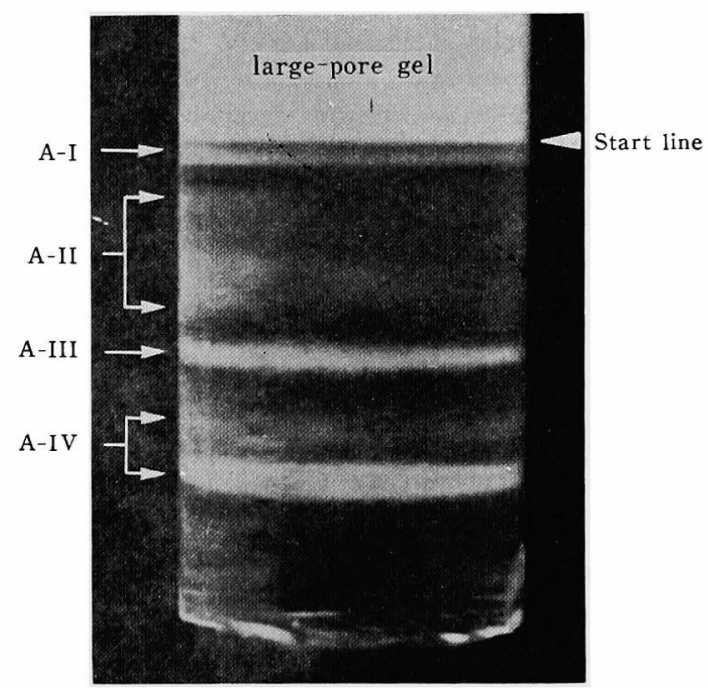

FIG. 2. Electrophoretic Diagram of Partially Purified NADPH-Cytochrome c Oxidoreductase.

A-I, brown layer

A-II, middle zone

A-III, yellow layer

A-IV, dark yellow layer

Each band shown in the photograph results from the color of protein.

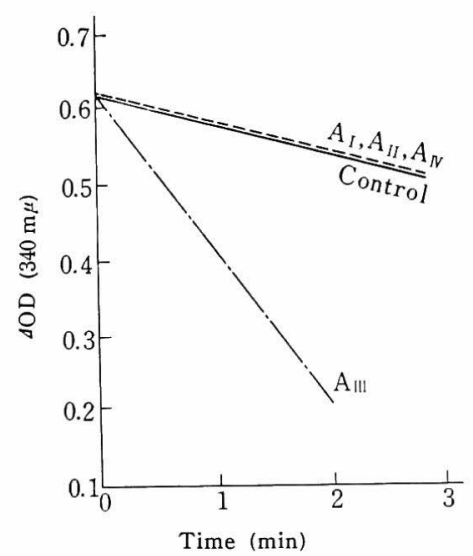

FIG. 3. Activity of Each Separated Layer.

Reaction mixture $(3.3 \mathrm{ml})$ :

Tris-HCl buffer ( $\mathrm{pH}$ 8.7), $100 \mu$ moles; Mb, $0.3 \mu$ moles; NADPH, $0.3 \mu$ moles; eluate of each layer, A-I (16 $\gamma$ protein), A-II (29 $\gamma$ protein), AIII (30 $\gamma$ protein), A-IV (36 $\gamma$ protein).
TABLE I. PURIFICATION OF NADPH-Cytochrome

c OXIDOREDUCTASE FROM Thiobacillus thiooxidans

$\begin{array}{lccc}\text { Fraction } & \begin{array}{c}\text { Total } \\ \text { protein } \\ (\mathrm{mg})\end{array} & \begin{array}{c}\text { Total } \\ \text { units }\end{array} & \begin{array}{c}\text { Specific } \\ \text { activity }\end{array} \\ \begin{array}{c}\text { Soluble fraction } \\ \text { Ammonium sulfate }\end{array} & 1800 & 2160 & 1.2 \\ \quad 106 & 201 & 1.9 \\ \begin{array}{c}\text { Amberionation } \\ \text { Amberlite treatment }\end{array} & 46 & 98 & 2.0 \\ \text { electrophoresis } & 6.9 & 17 & 25.2\end{array}$

The activities were assayed by the standard condition using mammalian cytochrome $\mathrm{c}$ as electron acceptor.

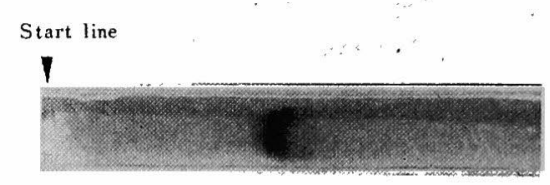

FIG. 4. Electrophoretic Pattern of Purified NADPH Cytochrome c Oxidoreductase.

Electrophoresis was carried out on $0.5 \%$ polyacrylamide gel $(3 \times 20 \mathrm{~cm})$ for approximately $8 \mathrm{hr}$ with $8 \mathrm{~mA} / \mathrm{cm}$.

The protein was detected by staining with amidoshwarz.

enzyme activity was found only in the fraction A-III (Fig. 3).

The purity of each step of the enzyme preparation is summarized in Table I.

Homogeneity of the enzyme

The fraction A-III was subjected to polyacrylamide gel electrophoresis. The electrophoretic pattern of the fraction A-III is shown in Fig. 4. The enzyme protein migrated at a single band as shown in the figure, and the location of that band was identical with that of yellow fluorescent band. Therefore, the preparation of NADPH-cytochrome c oxidoreductase should be respectably pure.

Acknowledgement. The authors wish to thank Mr. H. Tudaka for his assistance in the experimental work. 